\title{
DARI TRADISIONAL MENUJU DIGITAL: ADOPSI INTERNET OLEH NAHDLATUL ULAMA SELAMA PANDEMI COVID-19
}

\author{
Muhammad Irfan Wahid ${ }^{\mathrm{a}, 1}$, \\ ${ }^{a}$ Institut Agama Islam Negeri Palangka Raya, Palangka Raya 73112, Indonesia \\ ${ }^{1}$ mirfanw1@gmail.com
}

\begin{abstract}
ARTICLE INFO
ABSTRACT

Article history:

Received : 2019-12-31

Revised : 2020-05-27

Accepted : 2020-06-03

This article discussed on how religious organizations see and use the internet. The example of a case presented in this article was a mass organization of Nahdlatul Ulama. This article was based on assumption that Nahdlatul Ulama as a traditionalist religious

Keywords:

Nahdlatul Ulama

Traditional

Digital

Internet

Kata kunci:

Nahdlatul Ulama

Tradisional

Digital

Internet organization tends to be conservative towards the development of information technology was an inaccurate analysis. The data in this article were obtained from Nahdlatul Ulama official website and literature. The findings indicated that despite having a traditionalist character, Nahdlatul Ulama was able to adopt internet technology as an information media for its religious worldviews.

\section{ABSTRAK}

Artikel ini membahas tentang bagaimana organisasi keagamaan melihat dan menggunakan internet. Contoh kasus yang dikemukakan dalam artikel ini adalah ormas Nahdlatul Ulama. Artikel ini berargumen bahwa anggapan yang menyatakan Nahdlatul Ulama sebagai organisasi keagamaan tradisionalis cenderung konservatif terhadap perkembangan teknologi informasi adalah analisa yang tidak tepat. Data dalam artikel ini didapatkan dari literatur dan website resmi Nahdlatul Ulama. Temuan dalam artikel ini menunjukkan bahwa meskipun memiliki karakter tradisionalis, Nahdlatul Ulama mampu mengadopsi teknologi internet sebagai media informasi pandangan keagamaannya.
\end{abstract}

\section{Pendahuluan}

Wabah pandemi diyakini menjadi salah satu unsur yang turut berperan mendorong terjadinya perubahan zaman. Ketika zaman Purbakala, wabah melanda dan membawa serta abad baru yaitu Abad Pertengahan. Pandemi merubah tatanan dunia, pandemi juga dianggap berpengaruh nyata terhadap sistem politik, ekonomi dan budaya (Little, 2007, hlm. 11).

Pandemi Covid-19 kali ini pun membawa manusia kepada sebuah kebiasaan yang baru. Manusia tidak mungkin dapat kembali ke kehidupan normalnya yang dulu melainkan harus dapat beradaptasi cepat dengan DOI: 10.23971/jsam.v16i1.1745 kehidupan normal yang baru (Zizek, 2020, hlm. 3). Saat ini orang-orang terbiasa dengan perkembangan teknologi komunikasi sebagai sebuah public sphere baru.

Tidak dapat dipungkiri bahwa perkembangan dunia digital juga dapat mempengaruhi kehidupan manusia (Situmorang, 2012, hlm. 73). Perkembangan atau modernisasi, sebagaimana yang digunakan oleh (Peter L. Berger \& Luckmann, 1966), secara perlahan namun pasti masuk dalam lini kehidupan manusia dan menjadi pemantik perubahan sosio-kultural dalam masyarakat sosial (Peter Ludwig Berger, 1981). Karena itu, modernisasi tidak hanya dipahami dalam bentuk mentalitas saja, 
melainkan lebih jauh berubah dalam bentuk material empiris (Hardiman, 2004, hlm. 4).

Sebagai salah satu produk material empiris dari modernitas, kehadiran internet menjadi isu yang marak dibahas oleh para peneliti (Iqbal, 2017b, hlm. 9). Mereka menganggap bahwa bentuk baru dari media komunikasi ini diyakini menjadi indikasi perubahan sosial dalam masyarakat. Internet dianggap sebagai ruang publik baru di era modern (Jati, 2016, hlm. 28).

Beberapa waktu terakhir, marak kajian tentang Islam dan kaitannya dengan internet untuk menjawab polemik ketidaksepadanan antara agama dengan modernitas. Sebuah temuan yang dikemukakan oleh (Armfield \& Holbert, 2003) mengungkapkan bahwa "the more religious an individual is, the less likely he or she will use the Internet". Semakin tinggi tingkat relijiusitas seseorang maka akan cenderung tidak menggunakan internet (Fealy, 2012).

Argumen yang lahir dari etos pandangan dunia sekuler ini kemudian dikonfirmasi oleh temuan (Bockover, 2003) dan (Abdalla Uba Adamu, t.t.) yang menyatakan bahwa internet memiliki potensi negatif bagi agama karena dianggap menjadi media yang telah disisipkan sistem nilai tertentu seperti kapitalisme dan westernisasi.

Temuan Armfield dan Holbert yang telah disebutkan sebelumnya tadi juga dikuatkan oleh riset yang dilakukan (Al-Kandari \& Dashti, 2014). Kedua peneliti dari Arab Saudi ini mengungkapkan fakta tentang penolakan, tanggapan negatif dan sinis dari para ulama konservatif Arab Saudi terhadap awal-awal mula kemunculan internet di negara mereka. Selain hal itu, internet diyakini dapat menggerus otoritas keagamaan yang selama ini ada dan pakem dalam bentuk tradisional.

Hilangnya kepercayaan masyarakat terhadap otoritas keagamaan tradisional dan lemahnya kesadaran kolektif mereka terhadap keberagamaan merupakan akibat dari pengalaman keagamaan yang mereka dapatkan secara online (Barker, 2005, hlm. 80). Hal ini semakin tegas mengkonfirmasikan ketidaksepadanan antara agama dan internet.

Namun, di sisi lain, ketidaksepadanan ini dibantah oleh tulisan yang disampaikan oleh (Bunt, 2003). Menurutnya, religiusitas tidak menghalangi seseorang untuk menggunakan internet sebagai media komunikasi atau ruang publik baru. Dalam hal ini, religiusitas yang dimaksud oleh Bunt adalah agama Islam. Menurutnya, apabila indikasi keislaman dinilai dari jumlah penganut Islam dalam sebuah negara, maka bisa dikatakan penggunaan internet di negara-negara mayoritas Muslim justru menunjukan angka yang signifikan.

Statistik tahun 2000 yang dikutip oleh (Bunt, 2003) menunjukkan bahwa level akses internet oleh masyarakat Muslim adalah sebagai berikut: Turki memiliki 2,5 internet host per 1000 populasi. Malaysia sejumlah 2,4. Lebanon berjumlah 2,3. Oman dengan angka 1,4. Kyrgistan sejumlah 1,1. Kazakhstan sejumlah 0,6. Saudi Arabia dan Turkmenistan 0,3. Yordania, Senegal dan Indonesia di angka 0,2. Untuk negara Arab sendiri, Uni Emirat Arab mencapai angka tertinggi yaitu 20,9 per 1000 orang.

Temuannya juga menjelaskan bahwa semakin konservatif pemahaman religiusitas seseorang, tidak berpengaruh signifikan terhadap persepsinya ketika menggunakan media internet. Akan tetapi, justru menjelaskan sebuah fenomena baru tentang proses adopsi internet yang digunakan untuk kepentingan dakwah dan keislaman.

Hal ini kemudian dikuatkan oleh (Iqbal, 2017b) yang menemukan fakta bahwa kelompok Salafi Indonesia yang memiliki pandangan keagamaan ultra konservatif ternyata cenderung fleksibel dalam melakukan adopsi dan menggunakan internet sebagai resource penyebaran ideologi mereka. Mereka bertransformasi menjadi sebuah gerakan yang modern dan memiliki literasi teknologi yang baik.

Iqbal menyebutkan bahwa Salafi relatif berhasil melakukan "spiritualisasi internet" ketika mengadopsi dan mengadaptasikan internet sesuai dengan konteks keberagamaan mereka (Iqbal, 2017b, hlm. 289). Adopsi ini mencakup bagaimana gerakan ini mempromosikan ideologi Salaf mereka, menjawab isu-isu polemis tentang Salaf, menyikapi isu-isu lokal dan global kontemporer serta merekatkan jaringanjaringan internal mereka.

Temuan dari tersebut mengindikasikan bahwa proses adopsi internet yang dilakukan oleh kelompok Islam konservatif cenderung berlangsung lebih mudah dan cepat (Iqbal, 2017a, hlm. 99). Namun di lain sisi, khususnya di Indonesia, organisasi-organisasi 
keagamaan moderat seperti Nahdlatul Ulama (NU), Muhammadiyah dan Majelis Ulama Indonesia (MUI) cenderung sedikit lebih terlambat dalam mengadopsi produk modernisasi ini. Hal ini yang kemudian menjadi poin kritik yang disorot oleh (Hosen, 2008).

Menurut Hosen, telah terjadi fenomena perubahan sosial seiring dengan lahirnya internet dan keberagamaan siber (cyber spirituality). Masyarakat menemukan media baru dimana mereka dapat mengakses panduan-panduan keberagamaan dari internet. Dengan kemudahan dan kecepatan aksesnya, internet memudahkan siapapun untuk bisa mendapatkan informasi-informasi dan fatwafatwa keberagamaan. Namun, di sisi lain justru memunculkan sebuah kekhawatiran baru yang disebut sebagai fenomena anarki informasi (Hosen, 2008, hlm. 165).

Dengan sifatnya yang cepat dan anonim, internet membuka kesempatan bagi siapapun untuk menyajikan fatwa atau pandangan keagamaan secara cepat dan mudah. Hal ini menjadi bermasalah ketika kredibilitas mufti atau ulama tersebut tidak bisa dipertanggungjawabkan. Terkait dengan otoritas keagamaan di dunia siber, Derek mengklasifikasikan otoritas aktivis dunia siber Islam kepada dua kelompok. Yang pertama adalah aktivis siber Islam tradisionalis dan aktivis siber Islam progresif (Yusdani, 2015).

Penulis tidak sepenuhnya setuju dengan klasifikasi ini karena realita yang ada di Indonesia tidak seperti demikian. Sebagai contoh, Majelis Ulama Indonesia tidak hanya diisi oleh orang-orang yang memiliki latar belakang agama saja. Diantara mereka juga terdapat cendikiawan, akademisi, penulis dan lain-lain. Pokok perbedaan antara kedua aktivis siber tersebut ada pada kualifikasi mufti dan mekanisme ishdar fatwa. Aktivis tradisionalis mengharuskan seorang mufti memiliki latar belakang hukum Islam formal, berkarakter islami dan pandai berbahasa Arab. Sedangkan aktivis progresif bisa saja berasal dari bidang ilmu lain seperti sosiologi, ilmu politik, psikologi bahkan seniman. Mekanisme ishdar fatwa juga tidak sekaku aktivis tradisional.

Kedua kelompok aktivis siber yang telah sebelumnya disebutkan dapat diterima opini keagamaannya selama berada di bawah otoritas resmi dan bertanggungjawab. Namun yang menjadi permasalahan adalah tidak sedikit pula opini-opini tersebut lahir dari pandangan-pandangan individu. Opini individu ini terlebih dengan anonimitas justru akan melahirkan anarki informasi dan mengacaukan konstruksi ijtihad dalam Islam.

Pada konteks keindonesiaan, kosongnya otoritas keagamaan di dunia siber ini mengharuskan NU, Muhammadiyah dan MUI untuk secara cepat mengisi lini ini dengan mengadopsi dan mengadaptasikan internet sebagai media informasi keagamaan mereka. Sebagai organisasi Islam terbesar di Indonesia, peran ketiga organisasi ini dituntut untuk bisa hadir memberikan jawabanjawaban dan pandangan keagamaan tidak hanya di dunia nyata melainkan juga di dunia siber.

Muhammadiyah sendiri memiliki Himpunan Putusan Tarjih yang masih dipublikasikan secara konvensional kepada setiap simpatisannya. Mulai dari ustadz di surau, para guru dan dosen di lembaga pendidikan Muhammadiyah menggunakan buku ini sebagai referensi pandangan keagamaan Muhammadiyah. Sayangnya, kendati telah direvisi dan dicetak dengan tata letak yang lebih menarik, diseminasi buku ini masih menyisakan sebuah problem, yaitu sulit diakses oleh khalayak umum (Hosen, 2008, hlm. 232).

Di Majelis Ulama Indonesia (MUI) sendiri, kompilasi fatwa telah dipublikasikan sejak 1984 hingga sekarang. Serupa dengan permasalahan yang terjadi dalam diseminasi Himpunan Putusan Tarjih, Kompilasi Fatwa MUI juga kurang mampu mencapai khalayak masyarakat secara lebih luas. Hal ini kemudian menjadi perhatian dari pimpinan MUI sendiri yaitu Huzaemah Tahido Yanggo yang menyesalkan lemahnya distribusi kompilasi fatwa ini. Menurutnya, lemahnya sosialisasi fatwa-fatwa dan opini keagamaan justru akan melemahkan peran ulama yang seharusnya memberikan pencerahan kepada masyarakat (Hosen, 2008, hlm. 147).

NU sebagai organisasi keagamaan yang dianggap sebagai organisasi tradisionalis juga pernah mengeluarkan kompilasi fatwa yang dihimpun dan diedit oleh K.H. Azis Masyhuri (1997). Kompilasi fatwa yang kemudian diberi nama Masalah Keagamaan Hasil Muktamar dan Munas Ulama Nahdlatul Ulama 1926-1994 ini juga bernasib sama 
dengan kedua kompilasi fatwa dua organisasi yang telah disebutkan sebelumnya (Hosen, 2008, hlm. 5). Di era digital saat ini, kebutuhan informasi dalam bentuk publikasi cetak masih kurang diminati oleh masyarakat yang sudah mulai bergantung dengan kemudahan akses informasi menggunakan jaringan internet.

Otoritas keagamaan dituntut hadir di ruang publik baru seperti internet untuk menjawab isu-isu kontemporer, menuntaskan polemik keagamaan dan menyebarkan ideologi keislaman yang moderat. Dalam hal ini, NU sebagai salah satu organisasi keagamaan besar di Indonesia memiliki potensi untuk mengisi lini tersebut. Resource yang dimiliki NU untuk mengisi peran otoritas keagamaan di dunia siber semakin banyak seiring dengan munculnya tokohtokoh muda NU yang menggunakan platform media sosial untuk menebarkan ideologi moderat dan menjawab isu-isu keislaman kontemporer.

Dalam konteks Indonesia sendiri, pertentangan antara pandangan fatalisme dan determinisme dalam menghadapi pandemi Covid-19 ini menimbulkan resistensi pada lingkungan komunitas agama. Komunitas agama ini adalah pihak yang paling beresiko menjadi korban sekaligus transmitter penularan virus yang potensial. Ditambah lagi sentimen politik pasca peristiwa 212 dan Pemilu 2019 menambah rumitnya permasalahan ini. Karena itu, pemerintah tidak bisa mengabaikan peran organisasi keagamaan dalam menangani penebaran Covid-19.

Menurut (Muhtada, 2020), ada dua alasan mengapa pemerintah harus bekerja sama dengan organisasi keagamaan di Indonesia. Pertama, organisasi keagamaan seperti NU, Muhammadiyah dan MUI adalah organisasi yang memiliki otoritas untuk meluruskan pemahaman keagamaan yang keliru terkait bencana ini. Para tokoh organisasi tersebut, baik struktural maupun kultural dapat membantu memperbaiki pemahaman keagamaan yang fatalistis dalam menyikapi pandemi ini.

Kedua, struktur bertingkat yang dimiliki oleh organisasi keagamaan tersebut sangat potensial untuk bersinergi dalam upaya mitigasi bencana. Selain itu, organisasi keagamaan ini juga memiliki badan otonom yang dapat dikerahkan untuk mendukung tugas dan fungsi organisasi payungnya.

Berdasarkan kedua alasan tersebut di atas, tulisan ini hadir untuk melihat sejauh mana peran otoritas keagamaan Islam, khususnya Nahdlatul Ulama (NU) saat menggunakan internet sebagai media informasi mereka dalam upaya mitigasi bencana pandemi ini di Indonesia. Dengan berlandaskan pandangan bahwa internet dianggap mampu memberikan manfaat bagi Islam sebagai fasilitas bagi kepentingan dakwah dan corong informasi bagi para penganutnya.

\section{Tinjauan Pustaka}

Ada beberapa penelitian sejarah, sosiologi dan antropologi yang berkaitan dengan pemanfaatan internet oleh organisasi keagamaan atau komunitas keberagamaan. Secara umum, kajian ini berusaha untuk menjawab keraguan tentang kesepadanan agama dengan teknologi internet.

Dalam studinya, (Armfield \& Holbert, 2003) berkesimpulan bahwa semakin tinggi tingkat religiusitas seseorang maka akan cenderung tidak menggunakan internet.

Temuan ini dikonfirmasi oleh studi yang dilakukan oleh (Abdalla Uba Adamu, t.t.). Studi ini menyatakan bahwa penolakan sebagian penganut agama konservatif terhadap internet disebabkan oleh stigma negatif internet yang dianggap sebagai media yang disisipi nilai kapitalisme dan westernisasi. Hal ini dianggap bertentangan dengan ideologi agama Islam.

Begitu pula studi yang dilakukan oleh (Al-Kandari \& Dashti, 2014). Keduanya mengungkapkan fakta bahwa penolakan pemanfaatan internet sebagai media dakwah juga sempat terjadi di Arab Saudi. Penolakan ini dilakukan oleh ulama konservatif Arab Saudi.

Dari ketiga bukunya, Bunt menyatakan fakta bahwa telah terjadi pergeseran "battleground" diskursus keislaman dari dunia nyata menuju dunia maya. Bunt juga menyoroti tentang fatwa digital, jihad virtual hingga peretasan sistem keamanan digital atas nama Islam.

Fakta yang dikemukakan oleh Bunt ini dikonfirmasi oleh penelitian disertasi yang dilakukan oleh (Iqbal, 2017b). Dalam disertasinya tersebut, Iqbal mengungkap bagaimana kelompok Salafi di Indonesia yang 
dianggap konservatif ternyata lebih fleksibel dalam mengadopsi internet sebagai media dakwah mereka. Penelitian ini juga mengungkap bahwa kelompok Salafi yang memiliki kelemahan pendanaan dan logistik ternyata memanfaatkan internet sebagai media diseminasi pandangan keagamaan mereka.

Beberapa studi tersebut, belum ada yang menyoroti organisasi keagamaan tradisional seperti Nahdlatul Ulama. Sejauh penelurusan digital terhadap jurnal-jurnal, penulis hanya menemukan satu tulisan tentang peranan tim cyber NU Jawa Timur yang ditulis oleh (Utami \& Huda, 2017). Namun studi tersebut berfokus kepada peranan tim cyber tanpa menyoroti bagaimana muslim tradisional mengalami pergeseran kultur dari tradisional menuju digital.

\section{Metodologi Penelitian}

Tulisan ini menggunakan metode observasi online dengan tujuan untuk melakukan analisa terhadap konten yang disajikan dalam website Nahdlatul Ulama Online (NU Online).

Pengumpulan data yang diperlukan untuk tulisan ini didapatkan dari berbagai pilihan data yang relevan dengan isu-isu yang berkaitan dengan Covid-19 atau pandanganpandangan keagamaan yang disajikan dalam laman NU Online. Penelusuran langsung di laman situs www.nu.or.id milik Nahdlatul Ulama.

Untuk kepentingan tulisan ini, analisis difokuskan pada laman informasi atau pandangan keagamaan yang terdapat dalam situs resmi NU yaitu, www.nu.or.id. Pilihan ini didasarkan pada fakta bahwa situs ini menjadi sumber resmi informasi-informasi terkait NU. Selain itu, situs ini juga aktif dan banyak dikutip oleh laman-laman lain. Karena itu, hal ini dianggap memadai untuk dapat memberikan gambaran umum tentang penggunaan Nahdlatul Ulama di Indonesia atas internet.

Isi situs (web content) yang berupa artikel-artikel yang diterbitkan oleh redaksi situs dan kontributor dikumpulkan dari situs NU Online di atas untuk mengungkap caracara yang dipakai oleh Nahdlatul Ulama dalam menggunakan media internet sebagai respon mereka atas pandemi Covid-19.
Postingan tersebut dianalisis untuk mengungkap topik, argument dan tipe respon yang dikandungnya. Metodologi yang digunakan dalam analisis ini melibatkan penggunaan analisis tekstual dengan maksud mengungkap kategori-kategori dari penggunaan internet oleh NU. Dalam analisis ini, teks dipahami dalam bentuk artikel, laman, berita pada NU Online termasuk postingan dan gambar yang terdapat di situs tersebut.

Karena memperhatikan sifat internet yang dinamis dan cepat berubah, pengumpulan data dalam tulisan ini hanya difokuskan pada posting-posting konten pada bulan April dan Mei 2020.

\section{Hasil dan Diskusi}

\section{a. Nahdlatul Ulama: Sebuah Reaksi Anti- Modernitas?}

Secara umum, modernisme Islam dapat dimaknai dengan paham akan kebangkitan kembali Islam yang pernah terjadi di akhir abad 19. Akan tetapi, kebanyakan cendekiawan Islam lebih cenderung membedakan antara tema "modernisme" dan "pembaruan" (reformisme). Modernisme dianggap menekankan pada upaya pencarian relevansi terhadap masa kini bagi Islam sedangkan reformisme lebih terpusat pada upaya membersihkan iman dari berbagai bid'ah dan praktik-praktik yang dilarang.

Berbeda dengan kelompok Salafi yang konservatif. Menilik kepada sejarah lahirnya, NU yang lahir pada tahun 1926 dianggap sebagai simbol responsif Islam tradisional terhadap isu-isu dan aktifitas yang dilakukan kelompok reformis dalam skala lokal dan internasional. Kelahirannya tidak bisa dipisahkan dari gerakan-gerakan "kebangkitan" yang ada sebelum NU itu sendiri (Bruinessen, 1994, hlm. 13).

Pemaknaan dikotomis antara modernis dan tradisionalis sendiri sebenarnya menimbulkan permasalahan. Polarisasi ini melahirkan mispersepsi dan bias intelektual. Dalam konteks ini, tradisionalis lebih dianggap sebagai kelompok keagamaan yang ketinggalan jaman dan bergerak di pedesaan. Tradisionalis kerap dicap tidak intelektual, tidak canggih, oportunis secara politik dan sinkretis. Berbeda dengan modernis yang kerap dianggap sebaliknya. Kaum modernis 
diidentikkan sebagai kelompok yang maju, progresif, canggih, intelektual, dan inklusif (Qomar, 2002).

Sebagaimana yang dinyatakan oleh (Bruinessen, 1994) bahwa ajaran-ajaran muslim pembaru (reformis) dan modernis abad ke 19 dan 20 dapat dikatakan berlawanan dengan seluruh bangunan konsep kepercayaan dan amalan muslim tradisional. Apabila kaum Muhammadiyah dan PSII dikatakan sebagai kalangan pembaharu atau modernis, maka dapat dikatakan pula bahwa Nahdlatul Ulama sebagai kaum tradisionalis.

Polarisasi antara modernitas dan tradisionalis ini menurut (Fealy, 2012), lahir akibat pendekatan historis yang didominasi oleh kaum modernis. Pendekatan ini mulai digunakan pada awal 1950 hingga tahun 1970-an dan kemudian berubah menjadi pandangan konvensional bagi kalangan cendekiawan. Wacana yang disebut dominasi modernis ini bergerak dalam dua hal. Pertama, kaum modernis muslimlah yang dominan membentuk persepsi ilmiah dan jurnalistik tentang Islam Indonesia termasuk sikap negatif terhadap NU. Kedua, kaum modernis dan para peneliti Barat sama-sama telah terpukau oleh modernitas dan modernisasi yang mempengaruhi pandangan mereka terhadap budaya dan kepercayaan tradisional.

Akibatnya, NU sebagai organisasi muslim tradisionalis menjadi sasaran kritik kaum modernis dan pengamat Barat. Bagi kaum modernis, kaum tradisionalis dianggap sebagai mereka yang berkutat di permasalahan takhayul, tidak punya harapan, kuno dan tanpa berpikir mengekor kepada konsep dan praktik-praktik yang sudah ketinggalan jaman (Fealy, 2012, hlm. 7).

Sampai di sini, bukan berarti NU tidak merespon tuntutan-tuntutan modernitas. Kalau ditilik secara sadar, kehadiran NU sendiri sebagai sebuah organisasi keagamaan dan sosial adalah bagian dari modernisasi itu sendiri. NU tidak bisa menghindari perkembangan realitas dan modernitas yang ada zaman kini. Untuk itu, NU mengembangkan sebuah konsep untuk menjawab tantangan pembaruan tanpa merusak tradisi, sesuai dengan prinsip "almuhafazhatu 'ala al-qadim as-shalih wa alakhdzu bi al-jadid al-ashlah" berarti tetap memelihara nilai-nilai tradisional yang baik dan menggunakan nilai-nilai modern yang lebih baik.

Polarisasi ini seiring waktu mendapatkan kritik, diantaranya sebagaimana yang disampaikan oleh (Istoria, 2011). Menurutnya, dikotomi modernis dan tradisionalis sudah tidak relevan lagi saat ini. Dikotomi tersebut lahir dari pemikiran yang rancu tentang penyematan modernitas bagi sebuah kelompok yang memiliki paradigma ijtihad dan tajdid.

Miftahuddin menyatakan bahwa saat ini sulit untuk mengatakan bahwa NU sebagai organisasi tradisionalis. Karena sejak awal berdirinya, NU telah memanifestasikan pemikiran modern dalam konsep ideologinya yang inklusif, substansial, konvergen, manhaji dan bahkan cenderung liberal.

Sebagai organisasi besar Islam di Indonesia, NU memiliki pengalaman yang panjang untuk masih bisa menunjukkan eksistensinya hingga sekarang. Pengalaman itu menggambarkan dinamika perjalanan NU yang berusaha untuk tetap berpegang teguh pada prinsip dan tradisi Aswaja (Ahl alSunnah wa al-Jama'ah) yang menjadi ruh organisasinya. Dengan jargon "al-muhafazatu ala al-qadim al-salih wa al-akhdzu bi al-jadid al-aslah", NU memiliki semangat konservasi sekaligus semangat dinamisme untuk bisa mengadopsi hal-hal yang baru.

Apabila dikaitkan dengan munculnya fenomena internet baru-baru ini, NU sendiri sudah mendapatkan otokritik dari cendikiawan mudanya sendiri. Dalam tulisannya yang berjudul Online Fatwa in Indonesia: From Fatwa Shopping to Googling a Kiai, (Hosen, 2008) menyoroti upaya diseminasi fatwa-fatwa NU yang dihasilkan dalam forum Bahtsul Masail. Meski kritik itu juga ditujukan untuk dua organisasi besar lain, yakni Muhammadiyah dan Majelis Ulama Indonesia, Nadirsyah menyatakan bahwa ketiga organisasi besar ini harus bisa melakukan diseminasi fatwa secara lebih efektif di internet. Fasilitas cyber ini memungkinkan seorang muslim untuk berinteraksi dan mendapatkan akses informasi keislaman dengan mudah. Sekaligus mengantisipasi informasi-informasi yang lebih dulu dimanfaatkan oleh kaum radikal (Lim, 2005).

Otoritas keagamaan dituntut hadir di ruang publik baru seperti internet untuk menjawab isu-isu kontemporer, menuntaskan 
polemik keagamaan dan menyebarkan ideologi keislaman yang moderat. Dalam hal ini, NU sebagai salah satu organisasi keagamaan besar di Indonesia memiliki potensi untuk mengisi lini tersebut. Resource yang dimiliki NU untuk mengisi peran otoritas keagamaan di dunia cyber semakin banyak seiring dengan munculnya tokohtokoh muda NU yang menggunakan platform media sosial untuk menebarkan ideologi moderat dan menjawab isu-isu keislaman kontemporer.

\section{b. Pergeseran Kultur Tradisional, Post Tradisional dan Digital}

Sebagai organisasi besar Islam di Indonesia, NU memiliki pengalaman yang panjang untuk masih bisa menunjukkan eksistensinya hingga sekarang. Pengalaman itu menggambarkan dinamika perjalanan NU yang berusaha untuk tetap berpegang teguh pada prinsip dan tradisi Aswaja (Ahl alSunnah wa al-Jama'ah) yang menjadi ruh organisasinya. Dengan jargon "al-muhafazatu ala al-qadim al-salih wa al-akhdzu bi al-jadid al-aslah", NU memiliki semangat konservasi sekaligus semangat dinamisme untuk bisa mengadopsi hal-hal yang baru.

Dengan penekanan pada semangat konservasi dan dinamisme inilah, NU melalui dinamika historis dalam perkembangan pemikiran keagamaan kontemporer Islam. Perjalanan perkembangan ini kemudian melahirkan pergeseran pemikiran dan identitas baru seperti Islam Post Tradisionalis.

Gerakan yang dimotori anak-anak muda NU ini memiliki semangat untuk terus menerus kritis terhadap kemapanan doktrin dan tradisi. Hal ini lahir dari kesadaran generasi muda ini akan tuntutan untuk melakukan revitalisasi tradisi yakni menjadikan tradisi (turats) sebagai basis untuk melakukan transformasi (Aminuddin, 2018, hlm. 106).

Berdasarkan hal tersebut, post tradisional NU menjadikan tradisi sebagai basis epistemologinya sekaligus juga pijakan untuk melakukan perubahan dan melahirkan tradisi baru yang berakar dari etos progresif dalam transformasi pemikirannya.

Menurut (Rumadi, 2008), ada beberapa karakteristik yang menjadi ciri khas post tradisional NU. Yakni, pertama, upaya untuk melepaskan diri dari kungkungan tradisi. Dalam arti bahwa tradisi hanya menjadi dasar pijakan untuk melakukan transformasi. Kedua, post tradisional Islam ingin menjadikan masyarakat Islam sebagai masyarakat yang plural, egaliter demokratis dan berkeadilan ketimbang menjadi masyarakat yang hegemonik. Ketiga, gerakan post tradisional ini berupaya untuk melepaskan diri dari jerat harfiyah teks yang memuat pesan-pesan keagamaan melainkan melakukan obyektifisasi (maudhu'iyyah) dan rasionalisasi (ma'quliyyah) dari teks-teks tersebut.

Pergeseran kultur yang diusung generasi muda ini sejalan dengan teori Culture Shift yang dikemukakan (Inglehart, 1990) tentang bagaimana pergeseran kultur terjadi seiring dengan perubahan nilai yang ada dalam sebuah masyarakat. Penekanan penting dalam teori Inglehart ini adalah "that social change occurs as older generations are replaced by younger generations whose values are different".

Seiring dengan perkembangan teknologi, bergeser pula kultur manusia. Dan dalam hal ini, kebutuhan akan informasi terkait pandangan keagamaan dan otoritas keagamaan digital secara tidak langsung menyeret NU untuk sekali lagi melebarkan jangkauannya ke dunia digital. Terlebih dalam konteks wabah Covid-19 yang memaksa segala sesuatu harus berjarak. Satu-satunya public sphere yang tersedia adalah internet. Karena itu, NU dituntut untuk dapat hadir juga di dunia maya.

\section{c. Tentang Situs NU Online}

Situs yang dipilih untuk dikaji dalam tulisan ini adalah situs resmi Nahdlatul Ulama atau Suara Nahdlatul Ulama, www.nu.or.id. Dalam pelaksanaan redakturnya, situs ini diawasi dan disupervisi langsung oleh Ketua Umum Pengurus Besar Nahdlatul Ulama, Prof. Dr. KH. Said Aqil Sirodj, MA yang dicantumkan sebagai Dewan Penasehat Situs. Selain beliau, ada nama-nama lain sebagai Dewan Penasehat, seperti KH. Yahya C. Staquf, Drs. H. Imam Aziz, Dr. (HC). H. Helmy Faisal Zaini, Dr. H. Abdul Mun'im DZ dan H. Ulil Hadrawi, M.Hum.

Berlaku sebagai Pemimpin Umum dalam situs ini adalah Hari Usmayadi dan Direktur diisi oleh Mohamad Syafi' Alielha. Wakil Direktur diisi oleh H. Syaifullah Amin. Pemimpin Redaksi sendiri diisi oleh Ahmad Mukafi Niam dan jajaran redaksi yang 
berjumlah kurang lebih 28 orang. Selain staf redaksi, situs ini juga memiliki divisi IT \& Desain yang bertugas untuk memastikan operasional situs sesuai dengan mutu yang dituju. Selain itu, contributor yang berjumlah situs ini juga tersebar di berbagai wilayah di Indonesia ("Struktur," t.t.).

Situs ini didesain sebagai situs berbasis teks yang user friendly dengan desain warna putih sebagai latar tulisannya. Logo situs ini sendiri bertuliskan NU Online dengan kombinasi warna hijau pada tulisan NU dan hitam pada tulisan Online.

\section{nuonline}

Gambar 1. Logo Situs NU Online

Situs ini menggunakan bahasa Indonesia dalam setiap artikelnya. Selain itu, situs ini juga menampilkan grafis-grafis menarik serta foto-foto actual dalam setiap postingan-nya. Pada laman utama, struktur situs ini dapat dibagi menjadi empat bagian. Pada bagian pertama, yaitu header. Di header, situs ini menampilkan logo NU Online. Di bagian kiri atas header terdapat pilihan laman berupa Tentang NU, Redaksi dan Download. Di sebelah kanan situs ini ada jaringan peramban (link) yang menghubungkan pembaca situs ke platform aplikasi lain seperti Facebook, Twitter, Instagram dan kanal Youtube resmi milik NU.

Masih di bagian header, tersedia menumenu seperti Home, Warta, Fragmen, Keislaman, Wawancara, Opini, Seni Budaya, Taushiyah, Pendidikan Islam, Ekonomi, Mitra, Tokoh, Pustaka, Humor dan Video. Artikel-artikel yang dipublikasikan dalam situs ini merupakan tulisan-tulisan dari redaktur dan dari kontributor NU yang tersebar di berbagai wilayah di Indonesia.

\section{d. Pemanfaatan Ideologis: Meluruskan Pemahaman Fatalisme}

Sebagian umat beragama di Indonesia dianggap sulit untuk diajak bekerja sama dalam memerangi ancaman pandemi Covid19. Hal ini disebabkan oleh pemahaman keagamaan sebagian umat yang cenderung fatalistis dan deterministis. Pandangan ini menganggap bahwa segala sesuatu termasuk wabah ini terjadi atas kehendak Tuhan. Dalam pandangan ini, hidup dan mati adalah takdir yang tidak perlu ditakuti. Karenanya, sebagian umat tidak mengindahkan himbauan pemerintah untuk sementara melaksanakan ibadah di rumah masing-masing.

Untuk meluruskan pemahaman ini, NU menguraikan sebuah penjelasan dengan menggunakan pendekatan akidah dan fikih. Pendekatan tradisional ini dilakukan dengan mengutip dalil-dalil dan sumber-sumber dari beberapa kitab turats (tradisional) yang khas dikaji dalam komunitas NU.

NU sangat memegang teguh tradisi akidah Ahlu Sunnah wal Jamaah sebagaimana mereka tegaskan sebagai identitas organisasi mereka. Sebagaimana pula mereka menegaskan bahwa konsep madzhab yang mereka gunakan adalah mengikuti pendapat empat Imam madzhab (Hanafi, Maliki, Syafi' I dan Hanbali). Karena itu, tidak mengherankan dalam setiap argumen yang dikemukakan oleh NU adalah argumen yang dulu pernah disampaikan oleh madzhab-madzhab ini, setelah melewati proses tahqiq dan kontekstualisasi.

Dari segi akidah, pernyataan yang berbunyi bahwa segala sesuatu termasuk wabah terjadi atas kehendak Allah adalah pernyataan yang benar. Seorang muslim harus meyakini betul bahwa hanya Allah yang menentukan sakit atau tidaknya seseorang. Ini merupakan bagian dari ajaran akidah Ahlu Sunnah wal Jamaah yang tertuang dalam keyakinan bahwa Allah itu memiliki sifat Qudrah (Maha Kuasa). Namun, Rasulullah juga mengajarkan langkah-langkah mitigasi dari wabah tersebut sebagaimana anjuran beliau untuk menjaga higienitas makanan, mengisolasi area wabah dan melakukan pembatasan sosial (Ahmad, 2020).

Dalam melihat fenomena wabah ini, Islam mengajarkan bahwa ajaran tawakkal dan ajaran waspada harus berjalan beriringan. Dalam arti bahwa tidak ada pertentangan antara ajaran tawakal dengan ajaran waspada karena hal ini seperti apa yang diajarkan AlQuran dalam surah At-Taubah ayat 51.

\section{e. Pemanfaatan Polemis: Polemik Shalat Jumat Saat Wabah}

Karena penyebaran virus Covid-19 yang cepat, pemerintah kemudian memberikan himbauan kepada pengurus masjid untuk menghentikan sementara waktu pelaksanaan ibadah shalat Jumat, berjamaah dan segala bentuk peringatan yang melibatkan banyak jamaah. Hal ini kemudian menimbulkan 
sedikit resistensi di kalangan masyarakat. Hal ini kemudian yang menjadi pokok sebuah pertanyaan yang dilayangkan ke redaksi NU Online dalam rubrik Bahtsul Masail.

Sebagaimana lazim diketahui bahwa Bahtsul Masail adalah sebuah tradisi intelektual dalam komunitas NU di mana para santri di bawah bimbingan Kyai melakukan pengkajian intensif terhadap permasalahanpermasalahan dan melakukan kontekstualisasi teks yang mereka dapati di kitab-kitab turats tersebut. Bahtsul Masail ini kemudian menjadi salah satu karakteristik yang menonjol dalam komunitas tradisional NU.

Dalam jawaban rubrik tersebut dijelaskan bahwa shalat Jumat merupakan kewajiban yang diperintahkan dalam Al-Quran. Selain kewajiban, shalat Jumat juga memiliki keutamaan. Karena itu, umat muslim berlomba-lomba memanfaatkan waktu tersebut untuk melaksanakan ibadah. Namun demikian, kewajiban tersebut akan gugur karena uzur. Entah itu uzur yang bersifat kolektif-objektif maupun yang bersifat individual-subjektif.

Dalam hal ini, wabah Covid-19 adalah uzur yang bersifat kolektif-objektif dapat menular kepada siapa saja secara umum. Karena itu, berpandangan dengan pendapat dalam madzhab As-Syafi'i, kewajiban shalat Jumat saat wabah menjadi gugur (A. Kurniawan, 2020b).

Selain itu, dalam konteks Ushul Fikih, gugurnya kewajiban ini juga terkait dengan konsep Hifzhun Nafs dalam ushulus syariah (pokok syariat). Konsep Hifzhun Nafs dalam pandangan hukum Islam dianggap sebagai pendekatan preventif-antisipatif hukum yang diduga kuat oleh para ulama sebagai cara efektif dan cocok dalam pengendalian sosial (A. Kurniawan, 2020c).

\section{f. Penggunaan Kontekstual Internet: Merespon Isu-Isu Kontemporer}

Sesuai dengan arahan dari Ketua Umum Pengurus Besar Nahdlatul Ulama (PBNU) Prof. Dr. KH. Said Aqil Siradj, MA yang mendorong santri-santri untuk bisa menyesuaikan diri terhadap perkembangan zaman dengan melakukan inovasi-inovasi strategis. NU Online dituntut untuk responsif memberikan inovasi-inovasi terbaru dengan menyuguhkan ide-ide kemajuan serta menjawab problematika kontemporer yang terjadi di masyarakat.
Dorongan ini juga disertai dengan seruan bagi santri untuk melek teknologi di era perkembangan digital. Santri dituntut untuk memainkan peranannya, khususnya di media sosial untuk membendung paham-paham radikal dan ekstrimis yang diakibatkan oleh orang-orang yang tidak memahami agama dengan benar namun unggul dalam masalah media sosial. Sebagaimana dikutip langsung, KH. Said Aqil Siradj menyatakan: "Kita yang paham agama, tapi ga ngisi konten medsos. Yang ngisi medsos malah yang ga ngerti agama, maka isinya caci maki, mengkafirkafirkan orang karena yang mengisi konten medsos ga ngerti agama" (Sahal \& Ahmad, 2019).

Karena itu, dalam sebuah menu laman khusus berjudul "Bahtsul Masail" NU berusaha menyajikan jawaban-jawaban dari pertanyaan-pertanyaan yang dialamatkan kepada redaksi. Sedikit berbeda dari prosedur Bahtsul Masail yang umumnya dilakukan saat Munas dan Muktamar, Bahtsul Masail yang disajikan dalam situs ini merupakan jawaban dari para Kiyai atau Ulama NU yang memiliki kredibilitas dan kompetensi. Mereka diminta oleh Redaksi untuk membantu memberikan jawaban atas pertanyaan-pertanyaan yang ada.

Diantara permasalahan kontemporer yang ditanyakan adalah hukum menjaga jarak jamaah dan shaf shalat Jumat dari Covid-19 (A. Kurniawan, 2020a). Jawaban dari permasalahan tersebut adalah sebagaimana imbauan putusan LBM PBNU, Fatwa MUI dan imbauan Bimas Kemenag RI yaitu meniadakan pelaksanaan ibadah Jumat di daerah zona merah Covid-19. Jika pun ada pengurus masjid yang tetap bersikukuh untuk menyelenggarakan ibadah shalat Jumat, maka mereka dihimbau untuk tetap mematuhi petunjuk medis termasuk jarak antar jamaah dan jarak antar shaf untuk meminimalisir resiko.

Permasalahan kontemporer lain yang dijawab dalam Bahtsul Masail ini adalah plafon belanja penduduk terjangkit Covid-19 dalam kajian Fikih (Muntaha, 2020). Selain itu ada juga pertanyaan kepada redaksi tentang hukum menimbun masker saat wabah Covid-19 (Syamsudin, 2020). 


\section{g. Penggunaan Strategis Internet : Media Informasi Organisasi}

Dengan jaringan pengurus cabang yang tersebar secara meluas di seluruh Indonesia bahkan hingga ke luar negeri. NU memiliki prakiraan jumlah basis pendukung yang mencapai lebih dari 40 juta orang dari beragam profesi di berbagai wilayah. Disertai dengan akhir-akhir ini terjadi pergeseran basis pendukung yang sejalan dengan pembangunan dan perkembangan urbanisasi ("Basis Pendukung," t.t.).

Warga NU terlibat aktif dalam proses migrasi ke perkotaan untuk mengisi lini industri. Hal ini menuntut NU untuk bisa menyajikan informasi-informasi organisasi secara komprehensif dan jangkauan yang luas, worldwide. Karena itu, penggunaan internet sebagai media informasi organisasi menjadi sebuah keharusan tersendiri.

Yang pertama kali harus disampaikan sebagai informasi organisasi adalah tentang struktur kepengurusan organisasi itu sendiri. Pada laman Struktur disebutkan bahwa struktur organisasi NU terdiri dari beberapa lapisan struktural. Dimulai dari yang paling dasar yakni pengurus ranting di tingkat desa atau kelurahan, majelis wakil cabang di tingkat kecamatan, pengurus cabang di tingkat kabupaten/kota, pengurus wilayah di tingkat provinsi dan pengurus besar di tingkat pusat.

Lebih lanjut, masing-masing kepengurusan memiliki struktur kepengurusan sendiri yang terbentuk dari mustasyar (penasehat), syuriyah (pimpinan tertinggi) dan tanfidziyah (pelaksana harian). Namun, khusus untuk pengurus tingkat ranting, setiap kepengurusan terdiri dari syuriyah dan tanfidziyah.

Selain struktur kelembagaan sendiri, NU menampilkan lembaga-lembaga, badan otonom dan lajnah-lajnah dalam organisasinya. Namun, dalam tulisan ini hal tersebut tidak akan diuraikan secara terperinci karena bukan menjadi fokus yang dimaksud dalam bagian ini. Yang ingin difokuskan dalam tulisan ini adalah bagaimana $\mathrm{NU}$ mempublikasikan kegiatan jejaringnya yang tersebar di seluruh Indonesia dan luar negeri melalui laman situs mereka.

Di mulai di Indonesia sendiri, NU Online melakukan publikasi kegiatan sosial penanggulangan Covid-19 yang dilakukan pengurus wilayah dan pengurus cabangnya di seluruh Indonesia. Sebagaimana diwartakan bahwa NU Care-LAZISNU Lampung Tengah menyalurkan donasi kepada warga yang terdampak Covid-19 (A. S. Kurniawan \& Asrori, 2020). NU di Ogan Komering Ulu Timur juga turut membantu memperkuat ekonomi warga dengan meluncurkan beras Nusantara (Azis \& Muiz, 2020). Serta peran serta Satgas NU NTB yang menyalurkan alat perlindungan diri (APD) ke rumah sakit di Nusa Tenggara Barat (Hadi \& Muiz, 2020).

Untuk skala Internasional sendiri, berbagai kegiatan pengurus cabang luar negeri juga mendapat publikasi yang memadai. Diantaranya publikasi kegiatan Pengurus Cabang Istimewa Nahdlatul Ulama United Kingdom (PCINU UK) yang turut bergerak membantu WNI terdampat Covid-19 dengan mendirikan LAZISNU UK (Zayn \& Setiawan, 2020). Selain itu PCINU Malaysia juga turut melakukan kegiatan sosial berupa pembagian 5000 paket sembako saat pandemi Covid-19 (Mudzofar \& Arifin, 2020).

\section{Kesimpulan}

Kiranya argumen yang menyatakan bahwa agama, terlebih kaum tradisionalis, akan menolak untuk menggunakan internet adalah sebuah kesimpulan yang terburu-buru. Lebih lagi ungkapan yang menganggap bahwa semakin religius, maka akan menolak internet. Kesimpulan yang terburu-buru ini lahir dari pengamatan yang kurang tepat dan cara memandang Islam sebagai sebuah entitas yang monolitik.

NU yang selama ini dianggap sebagai kelompok tradisionalis nyatanya mampu menjawab tuntutan kehadiran mereka di dunia digital. Sebagaimana fleksibilitas mereka terhadap perubahan, NU mampu mengisi lini otoritas di dunia digital yang selama ini dikesankan terdistrupsi.

Peranan inilah yang harusnya diisi oleh otoritas keagamaan lain yang berhaluan moderat. Untuk menyeimbangkan informasi di dunia maya yang selama ini didominasi pandangan-pandangan yang disiarkan oleh akun-akun anonim atau haluan pemikiran ekstrim.

\section{Daftar Pustaka}

Abdalla Uba Adamu. (t.t.). Islam and the Internet. Diambil 1 Juni 2020, dari http://www.kanoonline.com/publications /islam_and_the_internet.htm 
Ahmad, A. W. (2020, Maret 16). Melihat Corona dari Perspektif Aqidah dan Fiqih. Diambil 1 Juni 2020, dari https://islam.nu.or.id/post/read/117874/ melihat-corona-dari-perspektif-aqidahdan-fiqih

Al-Kandari, A. A., \& Dashti, A. (2014). Fatwa and the Internet: A Study of the Influence of Muslim Religious Scholars on Internet Diffusion in Saudi Arabia. Prometheus, 32(2), 127-144. https://doi.org/10.1080/08109028.2014.9 98929

Aminuddin, L. H. (2018). Rekonstruksi Wacana Modernis-Tradisionalis: Kajian Atas Pemikiran Keislaman Muhammadiyah dan Nahdlatul Ulama Pasca Reformasi. Kodifikasia, 12(1), 93-112-112. https://doi.org/10.21154/kodifikasia.v12i 1.1426

Armfield, G. G., \& Holbert, R. L. (2003). The Relationship Between Religiosity and Internet Use. Journal of Media and Religion, 2(3), 129-144. https://doi.org/10.1207/S15328415JMR0 203_01

Azis, M., \& Muiz, A. (2020, April 28). Perkuat Ekonomi Warga, NU OKU Timur Luncurkan Beras Nusantara. Diambil 1 Juni 2020, dari https://www.nu.or.id/post/read/119522/p erkuat-ekonomi-warga--nu-oku-timurluncurkan-beras-nusantara-

Barker, E. (2005). Crossing the Boundary: New Challenges to Religious Authority and Control as a Consequence of Access to the Internet. Dalam Religion and cyberspace (hlm. 72-90). Routledge.

Basis Pendukung. (t.t.). Diambil 1 Juni 2020, dari /static/9/basis pendukung

Berger, Peter L., \& Luckmann, T. (1966). The Social Construction of Reality: A Treatise in the Sociology of Knowledge. Garden City: Doubleday.

Berger, Peter Ludwig. (1981). The Homeless Mind: Modernization and Consciousness. USA: Penguin Books.

Bockover, M. I. (2003). Confucian Values and the Internet: A Potential Conflict. Journal of Chinese Philosophy, 30(2), 159-175. https://doi.org/10.1111/1540-6253.00112

Bruinessen, D. M. van. (1994). NU; Tradisi, Relasi-Relasi Kuasa, Pencarian Wacana Baru. Yogyakarta: Lkis Pelangi Aksara.

Bunt, G. R. (2003). Islam in the Digital Age: EJihad, Online Fatwas and Cyber Islamic Environments. London: Pluto Press.

Fealy, G. (2012). Ijtihad Politik Ulama; Sejarah NU 1952-1967. Yogyakarta: Lkis Pelangi Aksara.
Hadi, \& Muiz, A. (2020, April 26). Cegah Covid19, Satgas NU NTB Peduli Berbagi APD ke Rumah Sakit. Diambil 1 Juni 2020, dari https://www.nu.or.id/post/read/119481/c egah-covid-19--satgas-nu-ntb-peduliberbagi-apd-ke-rumah-sakit-

Hardiman, F. B. (2004). Filsafat Modern: Dari Machiavelli sampai Nietzsche. Jakarta: Gramedia Pustaka Utama.

Hosen, N. (2008). Online Fatwa in Indonesia: From Fatwa Shopping to Googling a Kiai'.

Inglehart, R. (1990). Culture Shift in Advanced Industrial Society. Chichester: Princeton University Press.

Iqbal, A. M. (2017a). Agama dan Adopsi Media Baru: Penggunaan Internet oleh Gerakan Salafisme di Indonesia. Jurnal Komunikasi Indonesia, II(2), 77-88-88. https://doi.org/10.7454/jki.v2i2.7834

Iqbal, A. M. (2017b). Cyber-Activism and the Islamic Salafi Movement in Indonesia (PhD Thesis). Murdoch University.

Istoria, A. W. (2011). Runtuhnya Dikotomi Tradisionalis dan Modernis: Menilik Dinamika Sejarah Nahdatul Ulama dan Muhammadiyah. ISTORIA: Jurnal Pendidikan Dan Sejarah, 9(1). https://doi.org/10.21831/istoria.v9i1.625 8

Jati, W. R. (2016). Cyberspace, Internet dan Ruang Publik Baru: Aktivisme Online Politik Kelas Menengah Indonesia. Jurnal Pemikiran Sosiologi, 3(1), 25-35. https://doi.org/10.22146/jps.v3i1.23524

Kurniawan, A. (2020a, Maret 20). Hukum Menjaga Jarak Jamaah dan Shaf Shalat Jumat dari Covid-19. Diambil 1 Juni 2020, dari https://islam.nu.or.id/post/read/118000/h ukum-menjaga-jarak-jamaah-dan-shafshalat-jumat-dari-covid-19

Kurniawan, A. (2020b, Maret 25). Mengapa Umat Islam Tidak Shalat Jumat Karena Covid19? Diambil 1 Juni 2020, dari https://islam.nu.or.id/post/read/118200/ mengapa-umat-islam-tidak-wajib-shalatjumat-karena-covid-19-

Kurniawan, A. (2020c, April 2). Pencegahan Covid-19 dan Hifzhun Nafs dalam Ushul Fiqih Lintas Zaman (1). Diambil 1 Juni 2020,

dari https://islam.nu.or.id/post/read/118591/p encegahan-covid-19-dan-hifzhun-nafsdalam-ushul-fiqih-lintas-zaman--1-

Kurniawan, A. S., \& Asrori, M. (2020, Mei 1). NU Care-LAZISNU Lampung Tengah Salurkan Donasi kepada Warga Terdampak Corona. Diambil 1 Juni 2020, 
dari

https://www.nu.or.id/post/read/119653/n u-care-lazisnu-lampung-tengah-salurkandonasi-kepada-warga-terdampak-corona

Lim, M. (2005). Islamic Radicalism and AntiAmericanism in Indonesia: The Role of the Internet. Washington: East-West Center Washington.

Little, L. K. (2007). Plague and the End of Antiquity: The Pandemic of 541-750. Cambridge: Cambridge University Press.

Mudzofar, H., \& Arifin, S. (2020, April 26). 5000 Paket Sembako Dibagikan PCINU Malaysia saat Pandemi Covid-19. Diambil 1 Juni 2020, dari https://www.nu.or.id/post/read/119478/5 000-paket-sembako-dibagikan-pcinumalaysia-saat-pandemi-covid-19

Muhtada, D. (2020, Maret 24). Agama dan Mitigasi Wabah COVID-19. Diambil 1 Juni 2020, dari Https://csis.or.id/ website: https://csis.or.id/publications/agama-danmitigasi-wabah-covid-19/

Muntaha, A. (2020, Maret 29). Plafon Belanja Penduduk Terjangkit Covid-19 dalam Kajian Fiqih. Diambil 1 Juni 2020, dari https://islam.nu.or.id/post/read/118411/p lafon-belanja-penduduk-terjangkitcovid-19-dalam-kajian-fiqih

Qomar, M. (2002). NU “liberal”: Dari Tradisionalisme Ahlussunah ke Universalisme Islam. Bandung: Mizan.

Rumadi. (2008). Post-Tradisionalisme Islam: Wacana Intelektualisme Dalam Komunitas NU. Fahmina Institute.

Sahal, H., \& Ahmad, F. (2019, Oktober 22). Kiai Said: Santri Harus Inovatif, Cerdas, dan Melek Teknologi. Diambil 1 Juni 2020, dari https://www.nu.or.id/post/read/112487/k iai-said--santri-harus-inovatif--cerdas-dan-melek-teknologi

Situmorang, J. R. (2012). Pemanfaatan Internet Sebagai New Media Dalam Bidang Politik, Bisnis, Pendidikan dan Sosial Budaya. Jurnal Administrasi Bisnis, 8(1). Diambil dari http://journal.unpar.ac.id/index.php/Jurn alAdministrasiBisnis/article/view/418

Struktur. (t.t.). Diambil 1 Juni 2020, dari /static/12/struktur

Syamsudin, M. (2020, Maret 8). 3 Tanda Pedagang Masker Masuk Kategori Monopoli yang Haram. Diambil 1 Juni 2020, dari https://islam.nu.or.id/post/read/117582/3 -tanda-pedagang-masker-masukkategori-monopoli-yang-haram

Utami, H. P., \& Huda, M. S. (2017). Peranan Tim Cyber Nahdlatul Ulama Jawa Timur Dalam Meningkatkan Nilai-Nilai Aswaja. Jurnal Mediakita: Jurnal Komunikasi Dan Penyiaran Islam, 1(1). https://doi.org/10.30762/mediakita.v1i1. 537

Yusdani. (2015). Pemikiran dan Gerakan Muslim Progresif. EL TARBAWI, 8(2), 146-160.

Zayn, H., \& Setiawan, K. (2020, Mei 1). Bentuk LAZISNU, Nahdliyin Inggris Bantu WNI Terdampak Covid-19. Diambil 1 Juni 2020, dari https://www.nu.or.id/post/read/119642/b entuk-lazisnu--nahdliyin-inggris-bantuwni-terdampak-covid-19

Zizek, S. (2020). Pandemic!: COVID-19 Shakes the World. New York: John Wiley \& Sons. 